\title{
Interventions on reducing burnout in physicians and nurses: A systematic review
}

\author{
Aidin Aryankhesal ${ }^{1}$, Roghayeh Mohammadibakhsh*2, ${ }^{2}$,adollah Hamidi ${ }^{3}$, Saeideh Alidoost ${ }^{2}$, \\ Masoud Behzadifar ${ }^{4}$, Rahim Sohrabi ${ }^{5}$, Zeynab Farhadi²
}

Received: 27 Aug 2018

Published: $31 \mathrm{Jul} 2019$

\begin{abstract}
Background: Burnout is one of the main factors in reducing the performance quality among hospital staff. Appropriate interventions can reduce burnout among physicians and nurses and result in promotion of the quality of services provided at hospitals. The present study aimed to provide a more comprehensive understanding of the interventions on burnout reduction among hospital physicians and nurses.

Methods: Studies were searched from January 2000 to June 2017 in PubMed, Embase, Scopus, Cochrane, and Web of Science. Randomized clinical trials (RCTs) and pretest-posttest studies that had interventions to reduce the burnout of physicians and nurses were included. However, studies conducted on medical and nursing students and nonmedical providers or beyond hospitals were excluded.

Results: Based on the study inclusion criteria, 12 RCTs and 6 pretest-posttest studies were included in the review. Most of the included studies were from Netherlands, the United States, and England. The interventions included team-based program, EMHapproach, and coping and communication skills training. Most of the interventions had a positive effect on burnout reduction. Nevertheless, some studies had no significant impact.

Conclusion: The results showed that the most interventions used to improve burnout were improving communication skills, teamwork, participatory programs, and psychological interventions (Yoga, meditation, and mindfulness). The impact of these interventions can increase mental health in the long term. Burnout is a complicated problem and should be treated by combining interventions.
\end{abstract}

Keywords: Burnout, Mental health, Nurses, Physicians, Hospital, Systematic review

Conflicts of Interest: None declared

Funding: None

*This work has been published under CC BY-NC-SA 1.0 license.

Copyright $\odot$ Iran University of Medical Sciences

Cite this article as: Aryankhesal A, Mohammadibakhsh R, Hamidi Y, Alidoost S, Behzadifar M, Sohrabi R, Farhadi Z. Interventions on reducing burnout in physicians and nurses: A systematic review. Med J Islam Repub Iran. 2019 (31 Jul);33:77. https://doi.org/10.47176/mjiri.33.77

\section{Introduction}

Health is a right and an important need for all human beings, and its role in promoting human development indicators is undeniable. Social determinants of health (SDH) are considered as the most important factors in achieving health goals and establishing equity in health.
One of the most important SDH is the social status of people in exposure to unhealthy and stressful living and working conditions (1). Burnout is one of the factors affecting the quality of staff and worker's performance (2, 3 ). This phenomenon counts as a particular type of occu-
Corresponding author: Dr Roghayeh Mohammadibakhsh, mohamadibakhsh.r@tak.iums.ac.ir

1. Health Management and Economics Research Center, Iran University of Medical Sciences, Tehran, Iran

2. Department of Health Services Management, School of Health Management and Information Sciences, Iran University of Medical Sciences, Tehran, Iran

3. Department of Health Management and Economics, School of Public Health and Research Center for Public Health, Hamadan University of Medical Sciences, Hamadan, Iran.

4. Social Determinants of Health Research Center, Lorestan University of Medical Sciences, Khorramabad, Iran

5. Iranian Social Security Organization, Zanjan Province Health Administration, Zanjan, Iran

\section{$\uparrow$ What is "already known" in this topic:}

Burnout is an important problem for health workforce, with a strong impact on their quality of life and a corresponding decrease in the quality of care with an evident economic burden for the health care system.

\section{$\rightarrow$ What this article adds:}

This was the first systematic review to compare the interventions on physicians and nurses' burnout. These interventions can be used by policymakers, managers, researchers, and all those who are interested in improving mental health of physicians and nurses. 
pational reaction among professions resulted from mutual emotional relationships between service providers and their recipients. It is also a syndrome that causes physical and emotional exhaustion, depersonalization, feeling of failure, reduction in the power of adaptation to stressors, negative attitude towards job, and low self-efficacy (4-6). Hospital staffs, especially physicians and nurses, are particularly exposed to burnout due to the nature of their work, their interaction with patients, and observing their suffering $(7,8)$.

The effects of burnout can be investigated from personal and organizational aspects and they may lead to negative impacts on patients care, their dissatisfaction, increased medical errors, reduced working hours, and lack of sustainability in health care systems due to reduction in attempts, work commitment, and job termination, especially among nurses $(9,10)$. Therefore, recognition and prevention of burnout can play a key role in improving mental health, and thus improving the quality of services provided at hospitals. Accordingly, appropriate interventions, both at individual and organizational levels, should be performed to reduce burnout among hospital staff, especially in physicians and nurses.

Many studies have been done to reduce the burnout of physicians and nurses. In these studies, interventions, such as yoga and communication skills training, have been identified as interventions that have improved the burnout of physicians and nurses $(11,12)$. Another systematic review article examined the interventions for reducing physician burnout in 2015 (13). However, the present study reviewed these interventions over a longer period (up to 2017) and searched more databases. It also compared the interventions that were performed to reduce burnout in physicians and nurses.

Thus, this systematic review examined various interventions that reduced burnout in physicians and nurses. These interventions can be used by policymakers, managers, researchers, and all those who are interested in improving mental health of physicians and nurses.

\section{Methods}

\section{Literature search}

Five international academic databases (ISI/Web of Sciences, PubMed, Embase, Scopus, and Cochrane CENTRAL) were searched from January 2000 to June 2017 using the following string of keywords: ("Nurses" OR "Physicians") AND ("Burnout" OR "Depression" OR "Mental health") AND ("Randomized controlled trial" OR "Time series" OR "Pretest posttest" OR "Before-after study") AND "Hospital". In this study, Google Scholar was used to search gray literature. The reference list of included studies was also hand-searched to ensure that all relevant studies were considered. The results of the search are included in the EndNote X8 software.

\section{Inclusion and exclusion criteria}

In the first stage, the titles and the abstracts of the studies were independently examined by 2 researchers through which interventional studies on physicians and nurses' burnout were included. Noninterventional studies, studies not conducted at hospitals, studies conducted on medical and nursing students, review studies, the abstracts of the conferences, book chapters, and letters written to the editors were excluded in this study. Any disagreement between the researchers was resolved through consultation with a third researcher.

\section{Data extraction}

Data for the leading authors' name, country, period of research, study design, year of publication, participants, sample size, type of intervention, intervention effects, and other findings of the study were extracted by 2 members of the research team. Disagreements between the researchers were resolved through negotiation or referring to a third person as a referee.

\section{Quality assessment}

The methodological quality of studies included in the present systematic review was assessed using the "Critical Appraisal Skills Programme" (CASP) checklist (14).

In this study, the CASP checklist was used for RCT and time series studies and the JBI critical appraisal checklist for pretest-posttest studies. Then, studies that earned an intermediate and high score entered the study (15).

Scores below 7 were considered as "low quality", 7-8 "intermediate quality", and 9-10 "high quality".

\section{Results}

The electronic search of the databases led to identifying 2506 studies, and 5 studies were identified through hand searching of the last issues of journals, with the most papers identified through electronic database searching. After removing the duplicate studies, the titles and abstracts of 1965 studies were examined by 2 researchers independently for relevance, and finally 18 studies were included for the final analysis. The process of study identification and selection, based on the PRISMA, is presented in Figure 1.

The findings of this study indicated that only few studies have been conducted on occupational burnout of physicians and nurses. Selected studies in this paper were interventional studies, RCTs, and pretest- posttest studies.

Most included studies were from Netherlands, the United States, and England and were concluded during 20102017. Also, $50 \%$ of interventions had a positive impact on physicians' burnout and $67 \%$ a positive impact on nurses' burnout. Most interventions were similar in physicians and nurses, but the interventions performed on nurses were more diverse and sometimes the effects of the same intervention varied in different target groups.

The interventions in the included studies that were conducted to reduce burnout and to improve mental health of physicians and nurses are as follow:

\section{$E M H$ and $O P$}

E-mental health interventions are aimed to reduce specific mental health complaints or to enhance wellbeing. In the OP-care group who were screened positive on impaired work functioning and/or on any mental health complaints, the personalized feedback was followed by an 


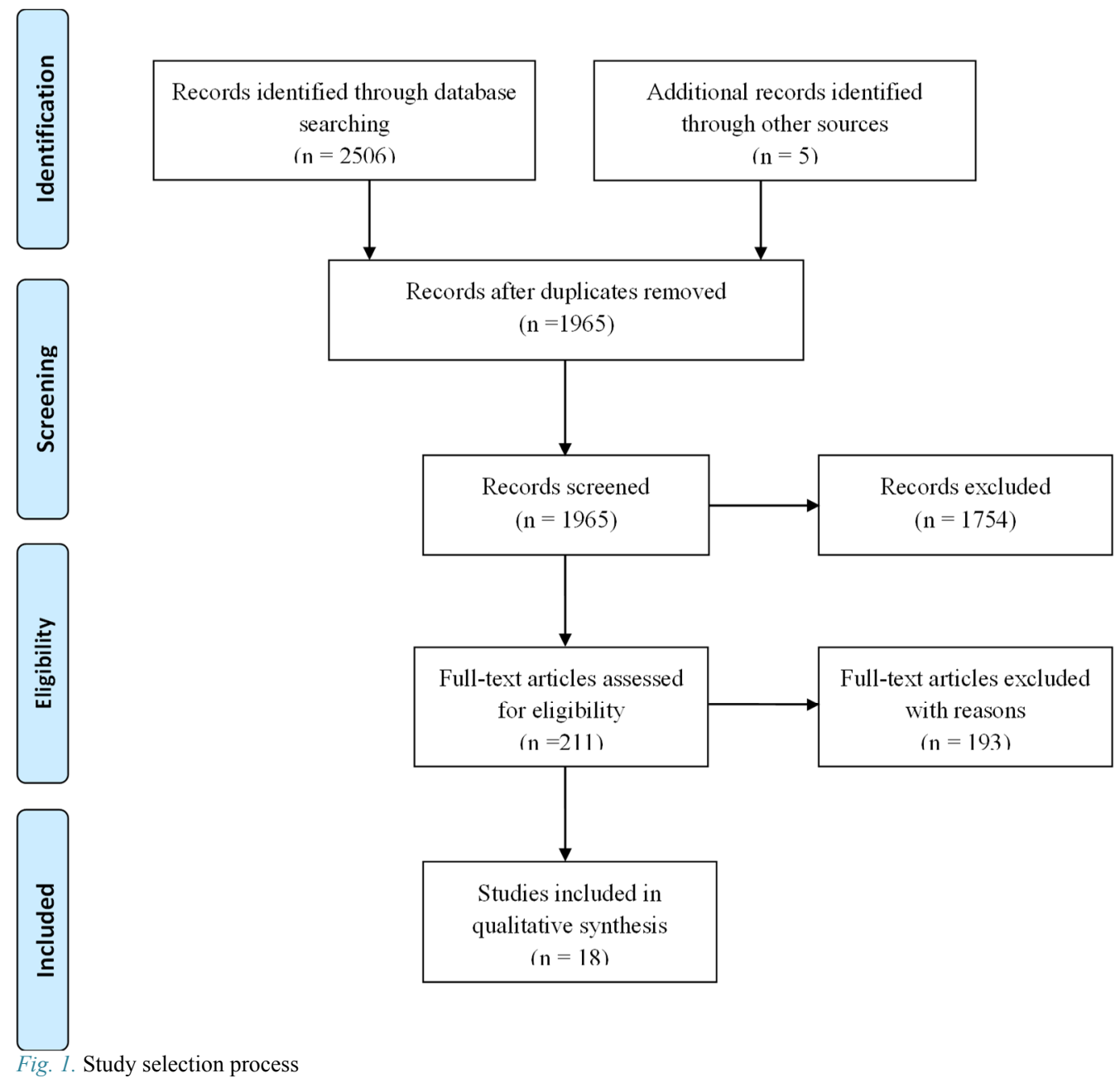

invitation for a face-to-face preventive consultation with their own occupational physician (OP). Both groups improved over time, and no significant difference was observed between intervention groups with EMH and OP approaches.

\section{Team-based interventions and participatory programs}

In all included studies, team-based and participatory programs had a non-significant effect. In this study, no significant relationship was observed between superiors' support and improvement in mental status of the staff, which indicates that improvement in mental health and symptoms of depression can be due to proper communication and participation of nurses on the same level, and not merely on the relationship with their superiors.

\section{Psychosocial training intervention}

Psychosocial training intervention significantly improved burnout rates. Nurse training, with broader range of interventions, helps the nurses to have more positive attitudes towards the patients.

\section{Psychiatric interventions}

Psychiatric interventions, such as Yoga and meditation, and mindfulness interventions led to a significant increase in self-care and a significant reduction in emotional exhaustion, stress, and burnout among physicians and nurses.

\section{Online programs and internet-based interventions}

Online intervention programs significantly improved mental health and reduced the symptoms of depression in the staff.

\section{Professional identity development program}

A professional identity development program can also reduce burnout of the nurses.

\section{Coping interventions}

Coping interventions led to a reduction in burnout among nurses, but the effect was no significant.

\section{Thankful events}

Workplace appreciation had a significant effect in increasing performance and reducing depression and burnout among nurses and physicians.

\section{Mix methods}

The use of integrated methods was shown to have a significant effect on reducing physicians and nurses' burnout.

Overall, most interventions intended to investigate the impact of training communication skills on burnout of physicians and nurses. In two thirds of the studies, the 
interventions had a positive impact on reducing burnout.

In $50 \%$ of the cases, communication skills training with

EMH approach had a significant effect on burnout. In

$75 \%$ of studies, psychiatric interventions had a significant effect on burnout. Also, in all studies, online interventions and professional identity development programs had significant effects on burnout. However, team-based and coping skills training had no significant effect on burnout. Nevertheless, mix methods had a significant effect on burnout in all studies.

Characteristics of the included studies on the interventions of physicians' burnout are presented in Tables 1 and 2.

Interventions and effects on burnout of physicians and

Table 1. Characteristics of the included studies on the interventions of physicians' burnout

\begin{tabular}{|c|c|c|c|c|c|c|}
\hline Author & Country & Participant & Intervention & $\begin{array}{l}\text { Effect of the } \\
\text { intervention }\end{array}$ & Main finding & $\begin{array}{c}\text { Quality } \\
\text { Assessment }\end{array}$ \\
\hline $\begin{array}{l}\text { Contratto } \\
2017 \\
(16)\end{array}$ & UK & $\begin{array}{l}7 \text { physi- } \\
\text { cians }\end{array}$ & $\begin{array}{c}\text { Computerized physician } \\
\text { order entry, electronic } \\
\text { health records }\end{array}$ & Positive & $\begin{array}{l}\text { Four months after the intervention, im- } \\
\text { provements were found in physicians' burn- } \\
\text { out. This study supports the use of physician } \\
\text { order entry clerical personnel as a simple, } \\
\text { cost-effective intervention to improve the } \\
\text { work lives of physicians. }\end{array}$ & 9 \\
\hline $\begin{array}{l}\text { Butow } \\
2016 \\
(17)\end{array}$ & $\begin{array}{l}\text { Australia/New Zealand } \\
\text { Swiss/Germany/Austria }\end{array}$ & $\begin{array}{l}95 \text { physi- } \\
\text { cians }\end{array}$ & $\begin{array}{l}\text { Consultation skills } \\
\text { training }\end{array}$ & Nonsignificant & $\begin{array}{l}\text { There were no significant differences in } \\
\text { burnout scores between the experimental } \\
\text { and control groups. } \\
\text { There were no significant differences in pre- } \\
\text { and postrandomization scores between the } \\
\text { experimental and control groups on other } \\
\text { stress and burnout subscales. }\end{array}$ & 9 \\
\hline $\begin{array}{l}\text { Noben } \\
2014 \\
(18)\end{array}$ & Netherlands & $\begin{array}{l}617 \text { physi- } \\
\text { cians }\end{array}$ & $\begin{array}{l}\text { EMH-approach consul- } \\
\text { tation with an occupa- } \\
\text { tional physician (OP) }\end{array}$ & Positive & $\begin{array}{l}\text { A significant improvement in work function- } \\
\text { ing occurred in the participating physicians. } \\
\text { The median incremental cost-effectiveness } \\
\text { ratio for the occupational physician condi- } \\
\text { tion versus the control condition was domi- } \\
\text { nant. }\end{array}$ & 9 \\
\hline $\begin{array}{l}\text { Linzer } \\
2015 \\
(19)\end{array}$ & USA & $\begin{array}{l}166 \text { physi- } \\
\text { cians }\end{array}$ & $\begin{array}{l}\text { Improved communica- } \\
\text { tion; changes in work- } \\
\text { flow, and targeted } \\
\text { quality improvement } \\
\text { (QI) projects }\end{array}$ & Positive & $\begin{array}{l}\text { More intervention showed significant effects } \\
\text { on reducing burnout. All } 3 \text { of the following } \\
\text { types of interventions led to improvements } \\
\text { in some staff outcomes: workflow, redesign, } \\
\text { and improved communication, especially } \\
\text { among physicians and staff. }\end{array}$ & 9 \\
\hline $\begin{array}{l}\text { Oman } \\
2006 \\
(20)\end{array}$ & USA & $\begin{array}{l}58 \text { physi- } \\
\text { cians }\end{array}$ & $\begin{array}{l}\text { Eight-point program } \\
\text { (EPP), a meditation- } \\
\text { based intervention }\end{array}$ & Nonsignificant & $\begin{array}{l}\text { A beneficial treatment effects were observed } \\
\text { on stress and mental health. Treatment ef- } \\
\text { fects on stress were mediated by adherence } \\
\text { to practices. Evidence suggests this program } \\
\text { reduces stress and may enhance mental } \\
\text { health. }\end{array}$ & 9 \\
\hline $\begin{array}{l}\text { Weight } \\
2013 \\
(21)\end{array}$ & USA & $\begin{array}{l}628 \text { physi- } \\
\text { cians }\end{array}$ & $\begin{array}{l}\text { Team-based, incentiv- } \\
\text { ized exercise program }\end{array}$ & Nonsignificant & $\begin{array}{l}\text { No significant differences were found be- } \\
\text { tween program participants and nonpartici- } \\
\text { pants. Burnout was lower in participants } \\
\text { than in nonparticipants, although the differ- } \\
\text { ence was not statistically significant. Resi- } \\
\text { dents and fellows may be much more seden- } \\
\text { tary than previously reported. }\end{array}$ & 9 \\
\hline
\end{tabular}

\begin{tabular}{|c|c|c|c|c|c|c|}
\hline Author & Country & Participant & Intervention & $\begin{array}{l}\text { Effect of the } \\
\text { intervention }\end{array}$ & Main finding & $\begin{array}{c}\text { Quality } \\
\text { Assessment }\end{array}$ \\
\hline $\begin{array}{c}\text { Cheng } \\
2015(22)\end{array}$ & China & 102 nurses & Thankful events & Positive & $\begin{array}{l}\text { The result shows a decrease in symptoms of depression. } \\
\text { However, this rate became less pronounced as time pro- } \\
\text { gressed. At follow-up, the gratitude group reported lower } \\
\text { depressive symptoms than control group. }\end{array}$ & 8 \\
\hline $\begin{array}{l}\text { Ketelaar } \\
2013(23)\end{array}$ & Netherlands & $\begin{array}{c}1140 \\
\text { nurses }\end{array}$ & $\begin{array}{l}\text { Electronic-mental } \\
\text { health care (EMH- } \\
\text { approach) } \\
\text { Consultation with } \\
\text { an occupational } \\
\text { physic-cian (OP) }\end{array}$ & Non-significant & $\begin{array}{l}\text { The OP-care approach trended towards better performance } \\
\text { in targeting work functioning, but findings showed that the } \\
\text { EMH care approach was noninferior. However, the high } \\
\text { dropout rate and low compliance to EMH interventions } \\
\text { should be considered. }\end{array}$ & 9 \\
\hline $\begin{array}{l}\text { Ketelaar } \\
2014(11)\end{array}$ & Netherlands & $\begin{array}{c}1170 \\
\text { nurses }\end{array}$ & $\begin{array}{c}\text { (EMH-approach) } \\
\text { with an (OP) }\end{array}$ & Non-significant & $\begin{array}{l}\text { It was not demonstrated that an EMH approach to WHS is } \\
\text { more effective to improve WF and } \mathrm{MH} \text {. The effect found } \\
\text { in the complete sample of participants could not be easily } \\
\text { interpreted. Reported results may be useful for future meta- } \\
\text { analytic work. }\end{array}$ & 9 \\
\hline $\begin{array}{l}\text { Uchiyama } \\
\text { 2013(24) }\end{array}$ & Japan & 434 nurses & $\begin{array}{l}\text { Participatory pro- } \\
\text { gram }\end{array}$ & Non-significant & $\begin{array}{l}\text { It is suggested that a 6-month intervention is effective in } \\
\text { improving psychosocial work environment, but it is not } \\
\text { effective in improving mental health of the nurses. }\end{array}$ & 8 \\
\hline
\end{tabular}




\begin{tabular}{|c|c|c|c|c|c|c|}
\hline Author & Country & Participant & Intervention & $\begin{array}{l}\text { Effect of the } \\
\text { intervention }\end{array}$ & Main finding & $\begin{array}{c}\text { Quality } \\
\text { Assessment }\end{array}$ \\
\hline $\begin{array}{l}\text { Alexander } \\
2015(12)\end{array}$ & USA & 40 nurses & Yoga & Positive & $\begin{array}{l}\text { Yoga participants reported high significant } \\
\text { self-care as well as less depressive symp- } \\
\text { toms upon completion of an 8-week yoga } \\
\text { intervention compared to control group. } \\
\text { Although the control group demonstrated } \\
\text { no change of the study, the yoga group } \\
\text { showed a significant improvement in scores } \\
\text { from pre- to postintervention. }\end{array}$ & 8 \\
\hline $\begin{array}{l}\text { Bolier } \\
2014(25)\end{array}$ & Netherlands & $\begin{array}{c}1140 \\
\text { nurses }\end{array}$ & $\begin{array}{l}\text { Online intervention group } \\
\text { (OI) or the wait listed } \\
\text { control group (WL) }\end{array}$ & Positive & $\begin{array}{l}\text { The intervention was capable of enhancing } \\
\text { positive mental health. However, due to a } \\
\text { high attrition rate, this result should be } \\
\text { considered with caution. }\end{array}$ & 8 \\
\hline $\begin{array}{l}\text { Darban } \\
2016(26)\end{array}$ & Iran & 60 nurses & $\begin{array}{l}\text { Communication skills } \\
\text { training }\end{array}$ & Positive & $\begin{array}{l}\text { Burnout in the intervention group improved } \\
\text { after the intervention. These changes sug- } \\
\text { gest a significant decreasing trend. On the } \\
\text { other hand, the mean scores of burnout in } \\
\text { the control group showed no significant } \\
\text { difference. }\end{array}$ & 8 \\
\hline $\begin{array}{l}\text { Sabanciogullari } \\
2015(27)\end{array}$ & Turkey & 63 nurses & $\begin{array}{l}\text { Professional identity de- } \\
\text { velopment program }\end{array}$ & Positive & $\begin{array}{l}\text { During the research period, burnout symp- } \\
\text { toms significantly declined in the interven- } \\
\text { tion group while those of the control group } \\
\text { increased. This program should be imple- } \\
\text { mented in different hospitals and different } \\
\text { samples of nurses. }\end{array}$ & 9 \\
\hline $\begin{array}{l}\text { Sallon } \\
2015(28)\end{array}$ & Israel & 164 nurses & $\begin{array}{l}\text { Intervention: cognitive, } \\
\text { somatic, dynamic, emotive } \\
\text { and hands-on (Yoga, medi- } \\
\text { tation, relaxation, touch } \\
\text { therapy, energy healing } \\
\text { (Reiki) }\end{array}$ & Positive & $\begin{array}{l}\text { These results encountered work stressors } \\
\text { impacts positively on health and well-being } \\
\text { and significantly reduces stress and burnout } \\
\text { among the nurses. }\end{array}$ & 8 \\
\hline $\begin{array}{l}\text { Ewers } \\
2010(29)\end{array}$ & UK & 33 nurses & $\begin{array}{l}\text { Psychosocial training } \\
\text { intervention (PSI) }\end{array}$ & Positive & $\begin{array}{l}\text { Staff in the intervention group showed } \\
\text { significant improvements in burnout rates, } \\
\text { while staff in the control group showed } \\
\text { increase in burnout. The findings indicate } \\
\text { that nurse training, with broader range of } \\
\text { interventions, helps them to be more posi- } \\
\text { tive in their attitudes towards the clients } \\
\text { that they work with. }\end{array}$ & 9 \\
\hline $\begin{array}{l}\text { Gunus } \\
2010(30)\end{array}$ & Turkey & 108 nurses & $\begin{array}{l}\text { Coping skills training a } \\
\text { support group }\end{array}$ & Nonsignificant & $\begin{array}{l}\text { Person-directed interventions can decrease } \\
\text { depression level. The fact that burnout } \\
\text { reduces after the intervention and an in- } \\
\text { crease is observed in } 6 \text { months is an im- } \\
\text { portant point. Thus, It is recommended that } \\
\text { the number of intervention studies to reduce } \\
\text { burnout be increased and that long-term } \\
\text { outcomes be evaluated. }\end{array}$ & 9 \\
\hline $\begin{array}{l}\text { Mackenzie } \\
2006(31)\end{array}$ & Canada & 30 nurses & $\begin{array}{l}\text { Mindfulness training is a } \\
\text { promising method for } \\
\text { helping those in the nurs- } \\
\text { ing profession; it manages } \\
\text { stress, even when provided } \\
\text { in a brief format. }\end{array}$ & Positive & $\begin{array}{l}\text { In this study, the findings indicate signifi- } \\
\text { cant improvements in burnout symptoms. } \\
\text { The results of this pilot study suggest that } \\
\text { mindfulness training is a promising method } \\
\text { for helping those in the nursing profession } \\
\text { to manage their stress. }\end{array}$ & 9 \\
\hline
\end{tabular}

nurses are demonstrated in Table 3.

\section{Discussion}

Burnout syndrome is an important health problem affecting many people, especially physicians and nurses and should be addressed globally with interventions at organizational and individual levels (32). Appropriate strategies to control burnout can be found in a range of identified interventions. The aim of this systematic review was to investigate the impact of conducted interventions on phy- sicians and nurses' burnout.

The identified interventions to reduce burnout and to improve mental health of physicians and nurses are as follow: motivational programs, communication training skills, electronic methods, psychiatric programs, and combined methods. Overall, most of studied interventions had reported positive impacts on reducing burnout and improving mental health.

Motivational programs, such as gratitude and thankful events, for physicians and nurses as well as professional 
Table 3. Interventions and their effect on burnout of physicians and nurses

\begin{tabular}{lccc}
\hline Interventions & Physicians & Effect & Nurses \\
\hline $\begin{array}{l}\text { Gratitude and thankful events } \\
\text { Professional identity development program }\end{array}$ & & & $*$ \\
$\begin{array}{l}\text { Communication skills training } \\
\text { Participatory program }\end{array}$ & $*$ & Positive & Positive \\
Peam-based program & $*$ & Nonsignificant & Positive \\
Consultation skills training & $*$ & Nonsignificant & Non-significant \\
EMH approach and OP approach & $*$ & Positive & $*$ \\
$\begin{array}{l}\text { Online programs and internet-based interventions } \\
\text { Psychosocial training intervention (PSI) }\end{array}$ & $*$ & & $*$ \\
$\begin{array}{l}\text { Coping skills training } \\
\text { Mindfulness training, Yoga, meditation, relaxation, }\end{array}$ & & & $*$ \\
touch therapy, energy healing (Reiki) & $*$ & Non-significant & Positive \\
Combination of above methods & $*$ & Nonsignificant & Non-significant \\
\end{tabular}

identity development programs can increase motivation and interest in caring for patients and can improve depression, burnout, and well-being. A study by Ziaei et al showed that proper human resource management, such as new approaches to encouragement and motivation, can reduce burnout in nurses and improve their mental health (33). The study of Ebrahimzadehpezeshki showed that the use of motivational methods can be effective in reducing the burnout of nurses, which is consistent with the findings of the present study (34). The role of communication skills training is important in reducing specific mental health complaints or enhancing well-being (26). The findings of the present study revealed that strengthening communication skills is more effective in reducing burnout in physicians than in nurses. In this context, Penberthy study is consistent with the present study which aimed at improving the communication skills of physicians (35). Team-based and participatory programs can help reduce symptoms of depression and improve mental health. A study conducted by Uchiyama suggested that the symptoms of depression and mental health can be improved in the hospitals where the possibility of visiting patients, receiving required information, and participation is high. Nevertheless, this finding should be interpreted with caution. The symptoms of depression appear in high stress conditions, so if milder symptoms, such as irritation, anger, and anxiety, are also examined, this intervention can have positive effects (24). In another study by Weight et al, the symptoms of burnout were milder in intervention group, using teamwork, compared to control group (21). Psychiatric programs (Yoga, meditation, and mindfulness programs) can help reduce burnout and improve mental health. Yoga practice may be an effective strategy to improve the health of nurses (12). Coping interventions can also lead to a reduction in burnout among nurses (30). Moreover, individual interventions can reduce emotional exhaustion. These findings were confirmed in a study by Lee et al, in which the role of copying strategies in reducing burnout of the nurses was examined. Lee's study showed that using copying interventions for 6 to 12 months can lead to a reduction in emotional exhaustion, depression, and ultimately burnout among nurses (9).

However, further research is required to confirm these results. Using larger sample sizes, more active control groups, dedicating more time to intervention, and using other interventions and comparing them with mentioned interventions, can make the study results more reliable.
Also, as burnout is a complex subject, it is better to use multiple methods to improve it. In Sallon study, with the aim of reducing burnout and improving mental health of nurses, mix interventions were used which resulted in a reduction in burnout among nurses (28). On the other hand, various studies have shown that burnout is affected by several factors that can act as facilitators or barriers of interventions to improve burnout, which should be considered. Age, sex, work experience, work environment, type of specialization, and income can affect the severity and weakness of job burnout. In this regard, some studies were shown that higher burnout levels could be increased due to the high demands, long working hours, insufficient income, a perceived mismatch between effort and reward, and poor organizational administration $(36,37)$. Workplace appreciation can also be effective in increasing performance, reducing depression, and improving burnout of nurses and physicians. Furthermore, the study of Viotti et al showed no statistically significant differences in the emotional exhaustion value between Intensive Care Unit (ICU) and non-intensive care unit (non-ICU) workers, although the average score is higher for non-ICU workers (38). The survey conducted by Medscape showed that specialties with the highest percentage of burnout are those that deal with severely ill patients (emergency medicine and critical care register $55 \%$ burnouts), and their physicians also reported a greater degree of severity in their burnout $(39,40)$.

Additionally, the results of this study indicated that various interventions can be used to improve the burnout of physicians and nurses, and their application should take into account the individual, organizational, specialty, and relevant aspects of the program. Therefore, these findings are not universal and their effect on burnout should be followed-up across other health care personnel and in different contexts over a longer period of time.

\section{Limitations}

The number of studies using the same interventions was too small, so generalizing the results should be done with caution. The number of participants in some studies was too low, which has led to a reduction in their statistical strength and an increase in inconsistency, reducing the effects of intervention. However, in some studies in which the sample size was large, no significant relationship was observed between intervention and burnout reduction. Demographic characteristics of the participants and heter- 
ogeneity of the groups can also affect the outcomes. In some cases, improving undesirable work conditions (staff shortage and insufficient salaries and benefits) were more effective in reducing the symptoms of depression and burnout than improving psychological conditions. The dispersion and multiplicity of mental health indices could also affect the outcomes of the study.

\section{Conclusion}

Different strategies, such as training and improving communication skills, yoga, and spiritual programs based on meditation, teamwork, computer programs, staff appreciation, and copying strategies can be used to reduce burnout among physicians and nurses. Training and improving communication skills were the most effective interventions to improve burnout in nurses and physicians. Undoubtedly, the results of interventions to reduce burnout and the indices related to mental health improvement will appear in the long run, and more follow-up studies are needed to trace the durability of the changes. Also, burnout in physicians and nurses is a complex problem that should be taken into consideration in interventions and if possible, combined and multidimensional interventions should be used. On the other hand, full implementation of these interventions can be costly and providing the necessary conditions, such as commitment of key individuals and preparing participants before the intervention, is highly important. Therefore, time, space, and feasibility limitations are the priority issues in applying such interventions.

\section{Conflict of Interests}

The authors declare that they have no competing interests.

\section{References}

1. MoH. The health and its social determinants. The main solution to expand justice in health and create a fair opportunity for everyone. Tehran: Moafagh; 2008.

2. Asuero AM, Queraltó JM, Pujol-Ribera E, Berenguera A, RodriguezBlanco T, Epstein RM. Effectiveness of a mindfulness education program in primary health care professionals: a pragmatic controlled trial. J Contin Educ Health Prof. 2014;34(1):4-12.

3. Ding Y, Yang Y, Yang X, Zhang T, Qiu X, He X, et al. The mediating role of coping style in the relationship between psychological capital and burnout among Chinese nurses. PLoS One. 2015;10(4):e0122128.

4. Hamidi Y.Strategic leadership for effectiveness of quality managers in medical sciences universities: What skills is necessary. Aust J Basic Appl Sci. 2009; 3(3):2563-2569.

5. Hamidi Y, Najafi L, Vatankhah S, Afkar A. The effect of performance appraisal results on the personnels motivation and job promotion. Aust J Basic Appl Sci. 2010;4(9):4178-83.

6. Leiter MP, Maslach C. Nurse turnover: the mediating role of burnout. J Nurs Manag. 2009;17(3):331-9.

7. Chou LP, Li CY, Hu SC. Job stress and burnout in hospital employees: comparisons of different medical professions in a regional hospital in Taiwan. BMJ Open.2014;4(2):e004185.

8. Poghosyan L, Clarke SP, Finlayson M, Aiken LH. Nurse burnout and quality of care: Cross-national investigation in six countries. Res Nurs Health.2010;33(4):288-98.

9. Lee HF, Kuo CC, Chien TW, Wang YR. A meta-analysis of the effects of coping strategies on reducing nurse burnout. Appl Nurs Res. 2016;31:100-10.

10. Aiken LH, Sermeus W, Van den Heede K, Sloane DM, Busse R, McKee M, et al. Patient safety, satisfaction, and quality of hospital care: cross sectional surveys of nurses and patients in 12 countries in
Europe and the United States. BMJ. 2012;344:e1717.

11. Ketelaar SM, Nieuwenhuijsen K, Gärtner FR, Bolier L, Smeets O, Sluiter JK. Mental Vitality@ Work: The effectiveness of a mental module for workers' health surveillance for nurses and allied health professionals, comparing two approaches in a cluster-randomised controlled trial. Int Arch Occup Environ Health. 2014;87(5):527-38.

12. Alexander GK, Rollins K, Walker D, Wong L, Pennings J. Yoga for self-care and burnout prevention among nurses. Workplace Health Saf. 2015;63(10):462-70.

13. Wiederhold BK, Cipresso P, Pizzioli D, Wiederhold M, Riva G. Intervention for physician burnout: A systematic review. Open Medicine. 2018;13(1):253-63.

14. CASP U. Critical Appraisal Skills Programme (CASP). Qualitative research checklist. 2017;31(13):449.

15. JBI Critical Appraisal Checklist for Quasi-Experimental Studies (non-randomized experimental studies), (2017).

16. Contratto E, Romp K, Estrada CA, Agne A, Willett LL. Physician Order Entry Clerical Support Improves Physician Satisfaction and Productivity. South Med J. 2017;110(5):363-8.

17. Butow P, Brown R, Aldridge J, Juraskova I, Zoller P, Boyle F, et al. Can consultation skills training change doctors' behaviour to increase involvement of patients in making decisions about standard treatment and clinical trials: a randomized controlled trial. Health Expect. 2015;18(6):2570-83

18. Noben C, Smit F, Nieuwenhuijsen K, Ketelaar S, Gärtner F, Boon $\mathrm{B}$, et al. Comparative cost effectiveness of two interventions to promote work functioning by targeting mental health complaints among nurses: Pragmatic cluster randomized trial. Investing in employability interventions? Int J Nurs Stud. 2014;51:1321-1331

19. Linzer M, Poplau S, Grossman E, Varkey A, Yale S, Williams E, et al. A cluster randomized trial of interventions to improve work conditions and clinician burnout in primary care: results from the Healthy Work Place (HWP) study. J Gen Intern Med. 2015;30(8):1105-11.

20. Oman D, Hedberg J, Thoresen CE. Passage meditation reduces perceived stress in health professionals: A randomized, controlled trial. J Consult Clin Psychol. 2006;74(4):714 -719.

21. Weight CJ, Sellon JL, Lessard-Anderson CR, Shanafelt TD, Olsen KD, Laskowski ER, editors. Physical activity, quality of life, and burnout among physician trainees: the effect of a team-based, incentivized exercise program. Mayo Clin Proc. 2013;88(12):143542.

22. Cheng ST, Tsui PK, Lam JH. Improving mental health in health care practitioners: Randomized controlled trial of a gratitude intervention. J Consult Clin Psychol. 2015;83(1):177-86.

23. Ketelaar SM, Nieuwenhuijsen K, Gärtner FR, Bolier L, Smeets O, Sluiter JK. Effect of an e-mental health approach to workers' health surveillance versus control group on work functioning of hospital employees: a cluster-RCT. PLoS One. 2013;8(9):e72546.

24. Uchiyama A, Odagiri Y, Ohya Y, Takamiya T, Inoue S, Shimomitsu T. Effect on mental health of a participatory intervention to improve psychosocial work environment: a cluster randomized controlled trial among nurses. J Occup Health. 2013;55(3):173-83.

25. Bolier L, Ketelaar SM, Nieuwenhuijsen K, Smeets O, Gärtner FR, Sluiter JK. Workplace mental health promotion online to enhance well-being of nurses and allied health professionals: A clusterrandomized controlled trial. Internet Interv. 2014;1(4):196-204.

26. Darban F, Balouchi A, Narouipour A, Safarzaei E, Shahdadi H. Effect of communication skills training on the burnout of nurses: a cross-sectional study. J Clin Diagn Res. 2016;10(4):IC01-IC04.

27. Sabanciogullari S, Dogan S. Effects of the professional identity development programme on the professional identity, job satisfaction and burnout levels of nurses: A pilot study. Int J Nurs Pract. 2015;21(6):847-57.

28. Sallon S, Katz-Eisner D, Yaffe H, Bdolah-Abram T. Caring for the caregivers: results of an extended, five-component stress-reduction intervention for hospital staff. Int J Behav Med. 2017;43(1):47-60

29. Ewers P, Bradshaw T, McGovern J, Ewers B. Does training in psychosocial interventions reduce burnout rates in forensic nurses? J Adv Nurs. 2010;37(5):470-6.

30. Günüșen N, Üstün B. An RCT of coping and support groups to reduce burnout among nurses. INT Nurs Rev. 2010;57(4):485-92.

31. Mackenzie CS, Poulin PA, Seidman-Carlson R. A brief mindfulness-based stress reduction intervention for nurses and nurse aides. Appl Nurs Res. 2006;19(2):105-9. 
32. West CP, Shanafelt TD, Kolars JC. Quality of life, burnout, educational debt, and medical knowledge among internal medicine residents. JAMA. 2011;306(9):952-60.

33. Ziaei M, Yarmohammadi H, Karamimatin B, Yarmohammadi S, Nazari Z, Gharagozlou F. Prevalence and risk factors of occupational burnout among nurses of a hospital in Kermanshah in 2013. Iran J Ergon. 2014;2(2):67-74.

34. Ebrahimzadehpezeshki R. Job burnout in nurses and its impact on their negligence. J Urmia Nurs. Midwifery Fac. 2017;15(2):86-94.

35. Penberthy JK, Chhabra D, Ducar DM, Avitabile N, Lynch M, Khanna S, et al. Impact of Coping and Communication Skills Program on Physician Burnout, Quality of Life, and Emotional Flooding. Saf Health Work. 2018;9:381-387.

36. Mohammed K, Ali EG, Youssef IM, Fahmy MT, Haggag WEL. Burnout and Personality among Egyptian Residents. Arab J Psychiatry. 2013;24(2):148-60.

37. Hamidi Y, Mohammadibakhsh R, Soltanian A, Behzadifar M. Relationship between organizational culture and commitment of employees in health care centers in west of Iran. Electron Physician. 2017;9(1):3646-3652.

38. Viotti S, Converso D, Loera B. Soddisfazione lavorativa e burnout in relazione alle caratteristiche del lavoro e alla tipologia dell'utenza: un confronto tra servizi di cura intensivi (ICU) e non intensivi (nonICU). G Ital Med Lav Ergon. 2012;34(2 Suppl B):52-60.

39. Gnerre P, Rivetti C, Rossi AP, Tesei L, Montemurro D, Nardi R. Work stress and burnout among physicians and nurses in Internal and Emergency Departments. Ital J Med. 2017;11(2):151-8.

40. Shanafelt TD, Hasan O, Dyrbye LN, Sinsky C, Satele D, Sloan J, et al., editors. Changes in burnout and satisfaction with work-life balance in physicians and the general US working population between 2011 and 2014. Mayo Clin Proc. 2015;90(12):1600-13. 